Article

\title{
Streamflow Trends and Responses to Climate Variability and Land Cover Change in South Dakota
}

\author{
Karishma Niloy Kibria ${ }^{1}$, Laurent Ahiablame ${ }^{1, *}$, Christopher Hay ${ }^{1,2}$ and Gemechis Djira ${ }^{3}$ \\ Received: 7 October 2015; Accepted: 24 December 2015; Published: 5 January 2016 \\ Academic Editor: Juraj Parajka \\ 1 Department of Agricultural and Biosystems Engineering, South Dakota State University, Brookings, \\ SD 57007, USA; Karishma.Kibria@sdstate.edu (K.N.K.); Christopher.Hay@sdstate.edu (C.H.) \\ 2 Iowa Soybean Association, Ankeny, IA 50023, USA \\ 3 Department of Mathematics and Statistics, South Dakota State University, Brookings, SD 57007, USA; \\ Gemechis.Djira@sdstate.edu \\ * Correspondence: Laurent.Ahiablame@sdstate.edu; Tel.: +1-605-688-5673
}

\begin{abstract}
Trends in high, moderate, and low streamflow conditions from United States Geological Survey (USGS) gauging stations were evaluated for a period of 1951-2013 for 18 selected watersheds in South Dakota (SD) using a modified Mann-Kendall test. Rainfall trends from 21 rainfall observation stations located within 20-km of the streamflow gauging stations were also evaluated for the same study period. The concept of elasticity was used to examine sensitivity of streamflow to variation in rainfall and land cover (i.e., grassland) in the study watersheds. Results indicated significant increasing trends in seven of the studied streams (of which five are in the east and two are located in the west), nine with slight increasing trends, and two with decreasing trends for annual streamflow. About half of the streams exhibited significant increasing trends in low and moderate flow conditions compared to high flow conditions. Ten rainfall stations showed slight increasing trends and seven showed decreasing trends for annual rainfall. Streamflow elasticity analysis revealed that streamflow was highly influenced by rainfall across the state (five of eastern streams and seven of western streams). Based on this analysis, a 10\% increase in annual rainfall would result in $11 \%-30 \%$ increase in annual streamflow in more than $60 \%$ of SD streams. While streamflow appears to be more sensitive to rainfall across the state, high sensitivity of streamflow to rapid decrease in grassland area was detected in two western watersheds. This study provides valuable insight into of the relationship between streamflow, climate, and grassland cover in SD and would support further research and stakeholder decision making about water resources.
\end{abstract}

Keywords: trend analysis; Mann-Kendall test; grassland; rainfall; elasticity coefficient; South Dakota

\section{Introduction}

South Dakota (SD) is located in the United States (US) Northern Great Plains region, which spans Montana, North Dakota, Wyoming, and Nebraska (in addition to SD) and is one of the largest prairie grasslands in the world [1]. Recent studies showed that grassland in SD is being lost to cropland [2,3], with more than $7410 \mathrm{~km}^{2}(4 \%)$ of grassland losses associated with a $10 \%$ increase in cropland i.e., cultivated lands excluding hay and alfalfa) and $2 \%$ increase in non-agricultural land uses between 2006 and 2012 [2]. In 2011 alone, approximately $1800 \mathrm{~km}^{2}$ of grassland was converted to cropland for corn production in the state [3].

The economy in SD relies greatly on agricultural activities with the production of corn, soybean, and wheat as the state's top commodity crops [4]. During the last few decades, corn and cattle are the two most important agricultural products, accounting for a little over one third of the total agricultural production of the state [4,5]. The Renewable Fuel Association ranked SD sixth in the US for corn 
production and fifth for corn grain ethanol production [6], making the state a leading corn production state for biofuel feedstock. The national interest to intensify renewable energy production [7] likely led to expansion of corn production as ethanol feedstock in SD and the region $[4,5,8]$.

There are two dominant land use types in SD, grassland and cropland, suggesting that the expansion of one would affect the other. Recent studies revealed that grassland conversion to cropland has been the main land use change in the western Corn Belt region [2,3]. Grassland represents a valuable resource for the Great Plains region [1]. When maintained well, grassland could have many environmental benefits such as promotion of wildlife habitat, provision of biodiversity, and beneficial controls on hydrologic processes [2]. Other important functions of grassland include its capacity to prevent flood by reducing surface runoff [9]. Besides preventing flood, providing a carbon sink to alleviate greenhouse gas emission, and providing feed for grazing [10], grassland contributes to erosion control and water quality regulation [11,12]. Schilling et al. [13] and Zhang and Schilling [14] showed that expansion of agricultural lands from sod-forming vegetation (e.g., pasture, hay, alfalfa) for soybean cultivation may have reduced evapotranspiration (ET), increased groundwater recharge, and increased stream discharge in the Mississippi River Basin. In the Raccoon River watershed in Iowa, increased corn production at the expense of grasslands played a major role in decreased annual ET, increased surface runoff, and increased water yield [15]. Land use and land cover change can contribute to alteration of surface runoff, flood frequency, baseflow, and annual mean discharge [16-18]. $\mathrm{Xu}$ et al. [19] reported that land use change as a result of cropland expansion contributed twice as much to streamflow changes compared to the effects of climate variability in 55 watersheds across the US Midwest. A substantial amount of increase in overland flow was predicted in Wisconsin and Michigan watersheds due to land cover change [20], with cropland expansion linked to an increase in flood peaks between mid-1920 and mid-1930 in Wisconsin [21].

Changes in streamflow characteristics can also be influenced by climatic factors $[17,22-29]$. The effects of climate on hydrology may include earlier snowmelt, change in streamflow timing, altered spring maximum flows, and intensified summer droughts [30-35]. Wet climate rather than land use change was shown to influence streamflow trends in the Upper Mississippi River Basin [22]. Mean annual streamflow changes in five major Minnesota River watersheds has been correlated with total annual rainfall [26]. The researchers in the later study reported substantial impact of increased rainfall events on peak flow increases in these watersheds [26], while rainfall was found to have a strong correlation with low flows rather than high flows in streams in Indiana [25]. Studies from other parts of the world also reported variation in streamflow with variation in climatic variables [24,25,36-38]. Rainfall decrease and temperature increase have been recognized as influential factors to streamflow decline in the Yellow River Basin in China [29]. Fluctuations in climate accounted for a $10 \mathrm{~mm}$ per year decrease in mean annual streamflow in the middle reaches of the Yellow River [23]. Along with land use change, climate change caused annual streamflow to increase by $4 \%$ in the Johor River Basin in Malaysia [17].

Previous studies on streamflow trends in the Great Plains and US Midwest regions generally reported upward trends in streamflow [39,40]. In the Missouri River Basin, trend analysis of annual streamflow between 1960 and 2011 indicated downward trends in the western and southern parts of the watershed while an upward trend was detected in the eastern part of the watershed [40]. While previous streamflow trend studies include SD watersheds, there is no known study, which exclusively focuses on hydrologic response to climate and local factors such as grassland losses. The objectives of this study were to use historical streamflow, rainfall, and land use data to (1) document long-term trend characteristics of streamflow and rainfall in SD watersheds; and (2) examine the relationships between streamflow, rainfall, and grassland cover. This study should provide useful insight into hydrological implications of climate variability and grassland cover change in the state. 


\section{Study Area}

South Dakota is located in the northern Great Plains region and has a total area of approximately $199,730 \mathrm{~km}^{2}$ of which nearly $62 \%$ of the total area is grassland [41-43]. According to the United States Department of Agriculture-National Resources Conservation Service (USDA-NRCS) [41], grassland in SD is comprised of a mixture of tall grass prairie and mixed grass prairie used for pasture, hay, and rangeland. The second leading land cover in the state is cropland that covers approximately $28 \%$ of the total area, while other land uses make up $11 \%$ of the total area [41,42]. As mentioned earlier, the increasing needs of bioenergy production likely increased agricultural activities, leading to grassland losses across the state [4]. In 2014, nearly $23,470 \mathrm{~km}^{2}(19 \%)$ of the total harvested land was used for corn production while $20,840 \mathrm{~km}^{2}(17 \%)$ of the total harvested land area was used for soybean production [44]. The total area of land harvested with corn and soybean is $43,830 \mathrm{~km}^{2}$, which accounts for $36 \%$ of total cultivated land in SD [44].

Agricultural activities in SD include livestock, poultry, and crop production. Crop production is mostly concentrated in the eastern part of the state, where the average rainfall is greater than in the western part [4,40]. The 30-year normal (1981-2010) annual precipitation varied from $430 \mathrm{~mm}$ to $660 \mathrm{~mm}$, following a northwest to southeast gradient [45]. Average monthly precipitation varies from $11 \mathrm{~mm}$ in February to $91 \mathrm{~mm}$ in July. The snowfall season varies from year to year, typically beginning in November and ending in March. The 30-year normal (1981-2010) annual snowfall depth ranged from $690 \mathrm{~mm}$ in Conde, SD to $5020 \mathrm{~mm}$ in Lead, SD [45]. South Dakota has an interior continental climate with hot summers and extremely cold winters. Monthly normal temperature ranges from more than $30^{\circ} \mathrm{C}$ in July to $-17^{\circ} \mathrm{C}$ in January in most of the state [45]. According to the World Atlas (www.worldatlas.com), the landscape of SD consists of four major regions, which are the drift prairie, till plains, Great Plains, and Black Hills. Land elevation ranges from $295 \mathrm{~m}$ in Big Stone Lake in eastern SD to $2207 \mathrm{~m}$ above sea level at Harney Peak in the Black Hills of western SD. The Missouri River, which flows generally north to south through SD bisects the state into eastern and western SD (Figure 1). The portion of the Missouri River that flows through the state is about $3770 \mathrm{~km}$. Other river systems such as the James River, White River, Little Missouri River, Big Sioux River, Cheyenne River, Belle Fourche River, Little White River, and Moreau River are tributaries of the Missouri River.

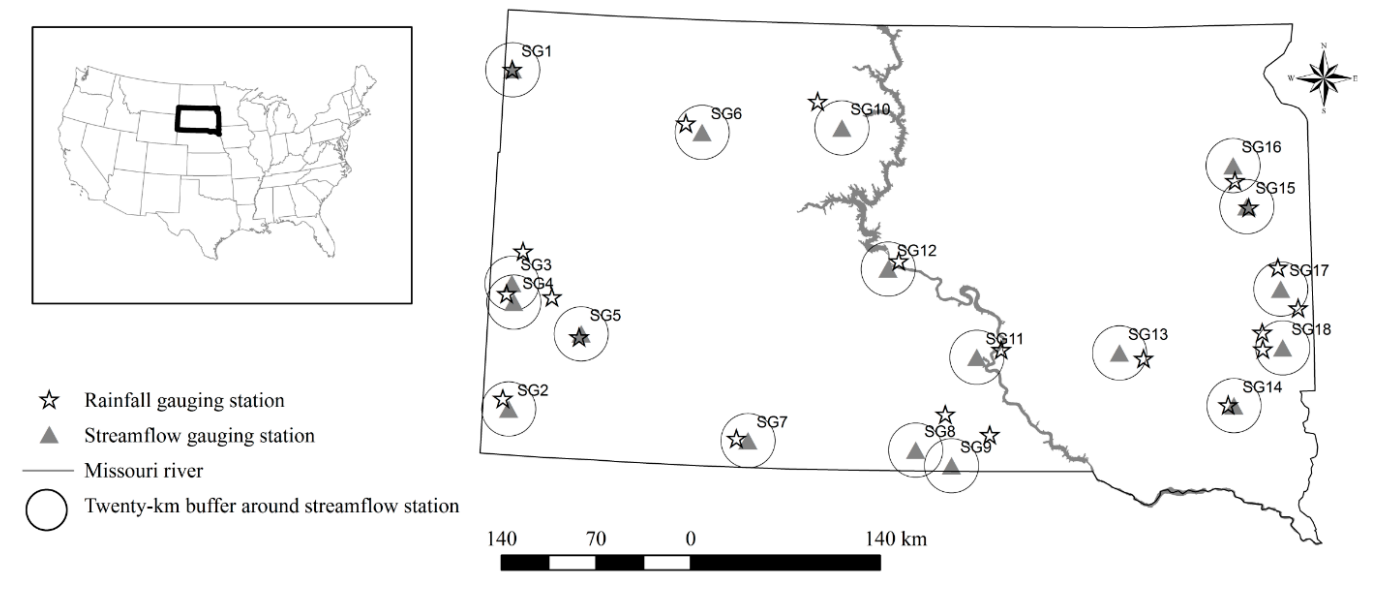

Figure 1. Map of South Dakota showing USGS stream gauging stations and rainfall gauging stations used in this study.

\section{Data Used}

Continuous daily streamflow data were extracted from the USGS National Water Information System (NWIS). The number of active streamflow gauging stations in SD is more than 150, which include stations with regulated and non-regulated flows. Daily streamflow data were compiled from 18 gauging stations selected out of the 154 stations (Figure 1; Table 1) using the following criteria: 
- The station must have at least 30 years of continuous streamflow data.

- The station must be free from diversion and regulation.

The 18 gauging stations used have 63 (1951-2013: 8 stations), 51 (1963-2013: 6 stations), 37 (1977-2013: 2 stations), and 32 years of data (1982-2013: 2 stations).

Table 1. List of streamflow and rainfall gauging stations used in this study.

\begin{tabular}{|c|c|c|c|c|c|}
\hline USGS Streamflow Station Name & $\begin{array}{c}\text { USGS Station } \\
\text { Number }\end{array}$ & Notation & Start Year & $\begin{array}{c}\text { Data Length } \\
\text { (Years) }\end{array}$ & $\begin{array}{c}\text { Drainage } \\
\text { Area }\left(\mathbf{k m}^{2}\right)\end{array}$ \\
\hline Bad River near Fort Pierre, SD & 06441500 & SG12 & 1951 & 63 & 8151 \\
\hline Battle Creek at Hermosa, SD & 06406000 & SG5 & 1951 & 63 & 438 \\
\hline Big Sioux River near Brookings, SD & 06480000 & SG17 & 1963 & 51 & 8645 \\
\hline Big Sioux River near Castlewood, SD & 06479525 & SG15 & 1977 & 37 & 2836 \\
\hline Big Sioux River near Dell Rapids, SD & 06481000 & SG18 & 1951 & 63 & 10,168 \\
\hline Big Sioux River near Watertown, SD & 06479438 & SG16 & 1977 & 37 & 1360 \\
\hline Castle Creek near Deerfield Res and Hill City, SD & 06409000 & SG4 & 1951 & 63 & 205 \\
\hline Cheyenne River at Edgemont, SD & 06395000 & SG2 & 1951 & 63 & 18,658 \\
\hline Firesteel Creek near West Vernon, SD & 06477500 & SG13 & 1963 & 51 & 1520 \\
\hline Keya Paha River near Keya Paha, SD & 06464100 & SG8 & 1982 & 32 & 1386 \\
\hline Keya Paha River at Wewela, SD & 06464500 & SG9 & 1951 & 63 & 2924 \\
\hline Little Missouri River at Camp Crook, SD & 06334500 & SG1 & 1963 & 51 & 5112 \\
\hline Little White River near Martin, SD & 06447500 & SG7 & 1963 & 51 & 811 \\
\hline Moreau River near Faith, SD & 06359500 & SG6 & 1951 & 63 & 6723 \\
\hline Moreau River near Whitehorse, SD & 06360500 & SG10 & 1963 & 51 & 12,675 \\
\hline Rhoads Fork near Rochford, SD & 06408700 & SG3 & 1982 & 32 & 20 \\
\hline West Fork Vermillion River near Parker, SD & 06478690 & SG14 & 1963 & 51 & 979 \\
\hline White River near Oacoma, SD & 06452000 & SG11 & 1951 & 63 & 25,693 \\
\hline Rainfall station name & \multicolumn{3}{|c|}{ Network ID } & \multicolumn{2}{|c|}{ Data length (years) } \\
\hline Brookings $2 \mathrm{NE}$, SD & \multicolumn{3}{|c|}{ GHCND: USC00391076 } & \multicolumn{2}{|c|}{51} \\
\hline Camp Crook, SD & \multicolumn{3}{|c|}{ GHCND: USC00391294 } & \multicolumn{2}{|c|}{51} \\
\hline Castlewood, SD & \multirow{2}{*}{\multicolumn{3}{|c|}{ GHCND: USC00391519 }} & \multicolumn{2}{|c|}{51} \\
\hline Chamberlin 5S & & & & \multicolumn{2}{|c|}{63} \\
\hline Chester, SD & \multicolumn{3}{|c|}{ GHCND: USC00391634 } & \multicolumn{2}{|c|}{63} \\
\hline Colton, SD & \multicolumn{3}{|c|}{ GHCND: USC00391851 } & \multicolumn{2}{|c|}{63} \\
\hline Deerfield 4 NW, SD & \multicolumn{3}{|c|}{ GHCND: USC00392228 } & \multicolumn{2}{|c|}{63} \\
\hline Edgemont, SD & \multicolumn{3}{|c|}{ GHCND: USC00392557 } & \multicolumn{2}{|c|}{63} \\
\hline Flandreau, SD & \multicolumn{3}{|c|}{ GHCND: USC00392984 } & \multicolumn{2}{|c|}{63} \\
\hline Gregory, SD & \multicolumn{3}{|c|}{ GHCND: USC00393452 } & \multicolumn{2}{|c|}{63} \\
\hline Hermosa 3 SSW, SD & \multicolumn{3}{|c|}{ GHCND: USC00393775 } & \multicolumn{2}{|c|}{51} \\
\hline Lead, SD & \multicolumn{3}{|c|}{ GHCND: USC00394834 } & \multicolumn{2}{|c|}{32} \\
\hline Marion, SD & GHCN & : USC0039 & & & \\
\hline Martin, SD & GHCN & ): USC0039 & & & \\
\hline Mitchell 2 N, SD & GHCN & : USC0039 & & & \\
\hline Pactola Dam, SD & $\mathrm{GHCN}$ & : USC0039 & & & \\
\hline Pierre Regional Airport, SD & $\mathrm{GHCN}$ & :USW0002 & & & \\
\hline Timber Lake, SD & GHCN & ): USC00398 & & & \\
\hline Usta 8 WNW Kelly Ranch, SD & GHCN & : USC00398 & & & \\
\hline Watertown Regional Airport, SD & GHCN & : USW0001 & & & \\
\hline Winner, SD & GHCN & ): USC0039 & & & \\
\hline
\end{tabular}

Continuous daily rainfall data were extracted from the National Oceanic and Atmospheric Administration (NOAA) database. A collocation approach was used to select rain gauging stations that were close to the selected streamflow observation stations. Saad et al. [46] and Ahiablame et al. [47] used collocation to select streamflow and water quality stations located together on the same river and within $5 \%$ of the watershed area. Following the same concept, $5 \%$ of the watershed area associated with each selected streamflow gauging station and corresponding radius were calculated. A fixed $20-\mathrm{km}$ buffer, which was created with the maximum of all 18 estimated radii, was used for all streamflow gauging stations to ensure that each streamflow gauging station has at least one rain gauging station within the 20-km buffer. Rainfall stations with daily rainfall data for more than 30 years (1951-2013) were selected. When more than one station falls within the same buffer zone, each station was accounted for individually and used for the analysis. In cases where there was no rain gauging that directly falls within the buffer, the closest rain gauging outside the buffer was used. Based on this 
technique, 21 rain gauging stations were utilized for the analysis (Figure 1; Table 1). The rainfall stations were chosen close to the streamflow gauging stations with the assumption that they accurately represent the rainfall in the study watersheds.

Land cover maps were extracted from the USGS Earth Resources Observation and Science (EROS) Center database (http://landcover-modeling.cr.usgs.gov/projects.php) and National Land Cover Database (NLCD) (http:/ / www.mrlc.gov/resources.php). EROS Center has annual land cover maps from 1938 to 1992 and NLCD has land cover maps for 1992, 2001, 2006, and 2011. These maps were used to estimate grassland area in the watersheds that drain into the 18 streamflow gauging stations selected in this study.

\section{Methodology}

\subsection{Computation of Streamflow, Rainfall, and Land Use Statistics}

The Indicators of Hydrologic Alteration (IHA) software [48] was utilized to compute six streamflow statistics that were used in trend analysis to represent low, moderate, and high streamflow conditions in SD. Low flow statistics, defined as streamflow values lower than 50 percentile of all daily flows, included one-day minimum and seven-day minimum; moderate flow statistics included median daily flow and average daily flow; and high flow statistics (defined as streamflow values greater than 75 percentile of all daily flows) included one-day maximum and seven-day maximum [48]. Total flows i.e., sum of daily flows per year and per season) were also computed to determine annual and seasonal variations. Median daily and daily average flows were computed by taking the median and average of daily flows per year, respectively. The seasons were defined as summer (June to August), fall (September to November), winter (December to February), and spring (March to May). Similarly, annual i.e., total rainfall in a year) and one-day maximum rainfall were calculated and used for the analysis.

To estimate grassland area in the study watersheds, land use maps were extracted from EROS land cover modelling database for 1951, 1961, 1971, and 1981, and NLCD for 1992, 2001, 2006, and 2011 using ArcGIS. The maps from both EROS land cover modelling database and NLCD have different classes. The grassland area used in this study corresponds to classes 11 and 14, which are grassland and hay/pasture in EROS land cover modelling database, and to classes 71 and 81 representing grassland/herbaceous and pasture/hay, respectively, in NLCD. These classes i.e., grassland and hay/pasture) were combined to estimate the total grassland area for each watershed.

\subsection{Trend Analysis}

The modified Mann-Kendall (MMK) test suggested by Hamed and Rao [49] was used in this study to detect trends in streamflow and rainfall. The modified approach of Mann-Kendall (MK) was adopted due to the presence of positive and negative serial correlation detected in the majority of streamflow and rainfall data after running Durbin-Watson tests $[50,51]$ for serial correlation. Serial correlation of hydrological time series data can result in overestimation and underestimation of existing trends $[25,49,52,53]$. The MK test statistic, $S$, is defined as [54]:

$$
S=\sum_{i=1}^{n-1} \sum_{j=i+1}^{n} \operatorname{sgn}\left(X_{j}-X_{i}\right)
$$

and

$$
\operatorname{sgn}(D)=\left\{\begin{array}{cll}
1 & \text { if } & D>0 \\
0 & \text { if } & D=0 \\
-1 & \text { if } & D<0
\end{array}\right.
$$

where $X_{i}$ and $X_{j}$ are the sequential data values, $n$ is the sample size, and $D$ is the difference between two sequential data values. The MMK statistic, $Z$, is given by $[25,49,53]$ : 


$$
Z=\left\{\begin{array}{ccc}
\frac{S-1}{\sqrt{V(S)^{*}}} & \text { for } & S>0 \\
0 & \text { for } & S=0 \\
\frac{S+1}{\sqrt{V(S)^{*}}} & \text { for } & S<0
\end{array}\right.
$$

and

$$
V(S)^{*}=V(S) \frac{n}{n^{*}}
$$

where $\mathrm{V}(\mathrm{S})^{*}$ is the modified variance of $\mathrm{S}$, and $\mathrm{V}(\mathrm{S})$ is defined as $[53,54]$ :

$$
V(S)=\frac{n(n-1)(2 n+S)}{18}
$$

and

$$
\frac{n}{n^{*}}=1+\frac{2}{n(n-1)(n-2)} \sum_{i=1}^{n-1}(n-i)(n-i-1)(n-i-2) r_{i}
$$

$\mathrm{r}_{\mathrm{k}}$ is the lag-k autocorrelation coefficient, computed as [25,53]:

$$
r_{k}=\frac{\frac{1}{n-k} \sum_{i=1}^{n-k}\left(X_{i}-\bar{X}\right)\left(X_{i+k}-\bar{X}\right)}{\frac{1}{n} \sum_{i=1}^{n}\left(X_{i}-\bar{X}\right)^{2}}
$$

A positive value of $Z$ indicates increasing or upward trend, while a negative $Z$ value suggests a decreasing or downward trend in the time series data [25,55]. The null hypothesis, $\mathrm{H}_{0}$, implies that there is no trend in the time series data, and was rejected at a significance level of $\alpha=0.10$ if $|Z|>Z_{(1-\alpha / 2)}$, where $Z_{(1-\alpha / 2)}$ is the value of the standard normal distribution with a probability of exceedance of $\alpha / 2$.

The magnitude of streamflow and rainfall trends were calculated using a nonparametric slope method proposed by Sen [56] and further discussed by Hirsch et al. [57]. The trend magnitude, $\beta$, was determined as [57]:

$$
b=\text { median }\left[\frac{X_{j}-X_{k}}{j-k}\right] \text { when }(1<\mathrm{k}<\mathrm{j}<\mathrm{n})
$$

$\mathrm{b}$ is the median for all possible combinations of pairs of any two data points in the entire dataset. $X_{j}$ and $X_{k}$ are the sequential data points, where $\mathrm{k}<\mathrm{j}$. A Microsoft Excel tool developed by Salmi et al. [58] was used to estimate streamflow and rainfall trend magnitudes in this study.

The trend analysis was conducted with all seven streamflow statistics (annual flow, one-day minimum, seven-day minimum, median daily flow, average daily flow, one-day maximum and seven-day maximum streamflow) and the two rainfall statistics (annual rainfall and one-day maximum rainfall).

\subsection{Streamflow Elasticity Analysis}

In this study, the effects of rainfall and land use change on streamflow were estimated by using the concept of elasticity $[59,60]$. The elasticity is represented by a coefficient, which characterizes changes in annual streamflow with respect to changes in annual rainfall and changes in grassland area. Streamflow elasticity i.e., sensitivity) to rainfall was defined as the proportional change in mean annual streamflow divided by the proportional change in mean annual rainfall [59-61]. If the elasticity coefficient is greater than 1 , a $1 \%$ change in annual rainfall would result in more than $1 \%$ change in annual streamflow. For example, an elasticity of +3 indicates that a $1 \%$ increase in annual rainfall would lead to $3 \%$ increase in annual streamflow. 
The nonparametric estimator of elasticity proposed by Sankarasubramaniam et al. [62] was used in this analysis to determine increase or decrease in annual streamflow as the result of increase or decrease in annual rainfall over a certain time period. The elasticity coefficient, $\varepsilon_{R}$, was calculated as:

$$
\varepsilon_{R}=\text { median }\left(\frac{Q_{t}-\bar{Q}}{R_{t}-\bar{R}} \overline{\bar{Q}}\right)=\text { median }(U)
$$

where $\bar{R}$ and $\bar{Q}$ are the mean annual rainfall and streamflow, respectively. A value of $U$ was calculated for each pair of $R_{t}$ and $Q_{t}$ in the annual time series. The elasticity coefficient was estimated by taking the median of all computed $U$ values. In this analysis, annual streamflow $\left(Q_{t}\right)$ and annual rainfall $\left(R_{t}\right)$ values were used to calculate streamflow elasticity to rainfall.

The principle of elasticity was also applied to determine elasticity of streamflow to change in grassland area. Grassland elasticity coefficient of streamflow, $\varepsilon_{\mathrm{L}}$, was defined as a ratio of the percentage of annual streamflow to the percentage of grass cover change. If $\varepsilon_{\mathrm{L}}$ is greater than 1 , a $1 \%$ change in grassland will result in more than $1 \%$ change in annual streamflow. The elasticity coefficient presented by Yao et al. [63] and Zheng et al. [64] was applied in this study and calculated as:

$$
\varepsilon_{L}=\frac{L_{(i+1)}-L_{i}}{Q_{(i+1)}-Q_{i}} \times \frac{\left(Q_{(i+1)}+Q_{i}\right) / 2}{\left(L_{(i+1)}+L_{i}\right) / 2}=\frac{\Delta L_{i}}{\Delta Q_{i}} \times \frac{\left(Q_{(i+1)}+Q_{i}\right)}{\left(L_{(i+1)}+L_{i}\right)}
$$

where $\varepsilon_{\mathrm{L}}$ describes the sensitivity of annual streamflow to change in grassland. $\mathrm{L}_{(\mathrm{i}+1)}$ and $\mathrm{L}_{\mathrm{i}}$ are estimated grassland areas for two consecutive time periods $(i+1)$ and $i$, which affect the corresponding mean annual streamflow $Q_{(i+1)}$ and $Q_{i}$. The elasticity coefficient was estimated by taking the mean of all computed grassland elasticity coefficient values for a specific station.

Unlike rainfall elasticity of streamflow, which was calculated using annual time series for both rainfall, and streamflow, grassland cover elasticity coefficients of streamflow were calculated between defined time periods because reliable annual grassland data were not available. Thus, streamflow data were divided into eight different time periods i.e., 1951-1955, 1956-1965, 1966-1975, 1976-1985, 1986-1995, 1996-2003, 2004-2008, and 2009-2013), and average annual streamflow was calculated for each time period. The eight time periods correspond to the eight land use maps i.e., 1951, 1961, 1971, 1981, 1992, 2001, 2006, 2011), which are single-year land use data. The time periods were defined as such to capture the effects of grassland cover change on streamflow prior to and after the publication year of a given land use map. For example, the time period of 1951-1955 and 1956-1965 correspond to 1951 and 1961 land use maps, respectively. Single-year grassland data (e.g., 1951, 1981, 2001, 2011) and corresponding average annual streamflow for a given time period were used in the computation of grassland cover elasticity coefficients.

\section{Results and Discussion}

\subsection{Trends in Streamflow and Rainfall}

The MMK Z-values, $\mathrm{p}$-values and magnitudes for streamflow and rainfall statistics are presented in Tables 2-5. Among 18 streamflow gauging stations, 39\% (seven stations) showed significant increasing trends and $12 \%$ (two stations) showed significant decreasing trends in annual streamflow (Figure 2; Table 2). Similar mixed patterns, in streamflow trends were reported in other parts of the Midwest and Great Plains regions. For example, significant increasing trends in streamflow were observed in most streamflow gauging stations in Kansas, Nebraska, and Oklahoma from 1922 to 2001 [65], and the Upper Mississippi River Basin [66]. Seasonal trend analysis showed that the number of streams with significant upward trends increased remarkably in fall (56\% of the stations) and winter (62\% of stations) compared to spring and summer seasons, in which streamflow trends were not significant in most of the streams (Tables 2 and 3). Out of the 18 streamflow gauging stations studied, only $23 \%$ of streams showed significant increasing trends in spring, and $34 \%$ showed significant 
increasing trends in summer (Tables 2 and 3). These increasing seasonal trends suggest that fall and winter in SD and perhaps in the High Plains region are getting wetter. Similar results were reported by Kustu et al. [67] who found significant increasing trends in fall streamflow in Illinois and Ohio watersheds. Norton et al. (2014) [40] also reported augmenting fall streamflow in the Missouri River Basin which drains SD. Climate may be the major contributor to the seasonal variability of streamflow trends [68] as warmer winter temperature reported in SD [68] may lead to early spring snowmelt, resulting in higher streamflow in winter and spring.

Table 2. Annual trends and trend magnitudes of streamflow in South Dakota. Modified Mann-Kendall Z-value, ( $p$-value) and [magnitude, $\mathrm{mm} /$ year] are shown. Values in bold represent statistically significant trends at $90 \%$ confidence level.

\begin{tabular}{|c|c|c|c|c|c|c|c|}
\hline $\begin{array}{c}\text { USGS } \\
\text { Station } \\
\text { Number }\end{array}$ & $\begin{array}{c}\text { Annual } \\
\text { Streamflow }\end{array}$ & $\begin{array}{c}\text { One-Day } \\
\text { Min } \\
\text { (Low Flow) }\end{array}$ & $\begin{array}{c}\text { Seven-Day } \\
\text { Min } \\
\text { (Low Flow) }\end{array}$ & $\begin{array}{c}\text { One-Day } \\
\text { Max } \\
\text { (High Flow) }\end{array}$ & $\begin{array}{c}\text { Seven-Day } \\
\text { Max } \\
\text { (High Flow) }\end{array}$ & $\begin{array}{c}\text { Median } \\
\text { Daily } \\
\text { (Flow) }\end{array}$ & $\begin{array}{c}\text { Daily } \\
\text { Average } \\
\text { (Flow) }\end{array}$ \\
\hline 06395000 & $-2.1(0.04)[-0.03]$ & $2.4(0.01)$ & $2.3(0.01)$ & $-2.7(0.01)$ & $-2.2(0.02)$ & $1.8(0.07)$ & $-2.0(0.04)$ \\
\hline 06409000 & $1.8(0.08)[0.41]$ & $1.5(0.12)$ & $1.6(0.11)$ & $1.9(0.05)$ & $1.6(0.09)$ & $1.8(0.07)$ & $1.8(0.08)$ \\
\hline 06441500 & $-0.5(0.62)[-0.03]$ & $1.1(0.25)$ & $1.9(0.05)$ & $-0.9(0.33)$ & $0.1(0.91)$ & $-0.5(0.64)$ & $-0.5(0.62)$ \\
\hline 06481000 & $1.8(0.08)[0.53]$ & $2.2(0.02)$ & $2.2(0.02)$ & $3.2(<0.10)$ & $2.9(<0.10)$ & $2.1(0.03)$ & $1.8(0.08)$ \\
\hline 06406000 & $1.7(0.09)[0.23]$ & $2.5(0.01)$ & $2.4(0.01)$ & $-0.1(0.93)$ & $0.9(0.35)$ & $2.0(0.04)$ & $1.7(0.095)$ \\
\hline 06360500 & $-3.9((<0.10)[-0.21]$ & $1.8(0.07)$ & $1.6(0.11)$ & $0.4(0.66)$ & $0.1(0.91)$ & $-2.5(0.01)$ & $-3.9(<0.10)$ \\
\hline 06477500 & $1.8(0.07)[0.23]$ & $2.5(0.01)$ & $2.8(<0.10)$ & $2.2(0.03)$ & $2.0(0.04)$ & $2.2(0.03)$ & $1.8(0.07)$ \\
\hline 06478690 & $2.5(0.01)[0.68]$ & $3.3(<0.10)$ & $3.4(<0.10)$ & $2.2(0.02)$ & $2.4(0.02)$ & $2.6(0.01)$ & $2.6(0.01)$ \\
\hline 06479438 & $1.5(0.13)[0.41]$ & $2.1(0.03)$ & $1.9(0.06)$ & $1.1(0.29)$ & $0.9(0.37)$ & $2.1(0.03)$ & $1.5(0.13)$ \\
\hline 06408700 & $0.2(0.82)[0.46]$ & $0.2(0.82)$ & $0.3(0.73)$ & $0.2(0.85)$ & $0.001(1.00)$ & $0.2(0.81)$ & $0.2(0.85)$ \\
\hline 06464100 & $0.1(0.86)[0.02]$ & $0.6(0.54)$ & $0.8(0.42)$ & $0.3(0.75)$ & $0.5(0.60)$ & $0.3(0.77)$ & $0.2(0.86)$ \\
\hline
\end{tabular}

Table 3. Seasonal trends and trend magnitudes of streamflow in South Dakota. Modified Mann-Kendall Z-value, ( $p$-value) and [magnitude, $\mathrm{mm}$ /year] are shown. Values in bold represent statistical significant trends at $90 \%$ confidence level.

\begin{tabular}{|c|c|c|c|c|}
\hline USGS Station Number & Fall & Spring & Summer & Winter \\
\hline 06359500 & $2.67(0.01)[0.004]$ & $1.27(0.20)[[0.015]$ & $0.17(0.86)[[0.001]$ & $2.60(0.01)[0.006]$ \\
\hline 06395000 & $1.72(0.09)[0.001]$ & $1.38(0.17)[[0.002]$ & $-1.99(0.05)[-0.008]$ & $2.17(0.03)[0.002]$ \\
\hline 06409000 & $0.48(0.63)[[0.002]$ & $0.91(0.36)[[0.003]$ & $0.92(0.36)[[0.0025]$ & $0.26(0.79)[[0.001]$ \\
\hline 06441500 & $0.32(0.75)[[0.0001]$ & $-0.50(0.62)[-0.004]$ & $-0.97(0.33)[-0.007]$ & $0.82(0.41)[[0.001]$ \\
\hline 06452000 & $1.69(0.09)[0.011]$ & $0.84(0.39)[[0.016]$ & $0.50(0.62)[[0.006]$ & $1.94(0.05)[0.013]$ \\
\hline 06464500 & $1.35(0.18)[[0.013]$ & $0.94(0.35)[[0.021]$ & $1.69(0.09)[0.026]$ & $1.48(0.14)[[0.023]$ \\
\hline 06481000 & $2.32(0.02)[0.055]$ & $1.72(0.08)[0.172]$ & $1.76(0.08)[0.106]$ & $2.09(0.04)[0.007]$ \\
\hline 06406000 & $2.00(0.05)[0.056]$ & $1.58(0.11)[[0.048]$ & $1.50(0.13)[[0.037]$ & $2.48(0.01)[0.047]$ \\
\hline 06360500 & $-5.33(<0.10)[-0.002]$ & $-4.41(<0.10)[-0.066]$ & $-3.46(<0.10)[-0.027]$ & $-2.42(0.02)[-0.001]$ \\
\hline 06477500 & $2.55(0.01)[0.001]$ & $1.44(0.15)[[0.021]$ & $2.68(0.01)[0.049]$ & $3.10(<0.10)[0.002]$ \\
\hline 06478690 & $2.94(<0.10)[0.007]$ & $2.06(0.04)[0.110]$ & $3.54(<0.10)[0.087]$ & $2.86(<0.10)[0.009]$ \\
\hline 06334500 & $0.39(0.69)[[0.0013]$ & $-0.46(0.64)[-0.015]$ & $-1.12(0.26)[-0.017]$ & $0.70(0.48)[[0.001]$ \\
\hline 06447500 & $1.25(0.21)[[0.008]$ & $1.11(0.27)[[0.023]$ & $0.14(0.89)[[0.003]$ & $1.97(0.05)[0.027]$ \\
\hline 06480000 & $2.41(0.02)[0.065]$ & $1.79(0.07)[0.209]$ & $1.91(0.06)[0.12]$ & $2.23(0.03)[0.039]$ \\
\hline 06479525 & $2.17(0.03) 0.043]$ & $1.92(0.05)[0.171]$ & $1.79(0.07)[0.064]$ & $2.16(0.03)[0.025]$ \\
\hline 06479438 & $2.24(0.02) 0.036]$ & $1.55(0.12)[[0.139]$ & $1.24(0.21)[[0.035]$ & $2.03(0.04)[0.017]$ \\
\hline 06408700 & $-0.01(0.99)[-0.01]$ & $0.33(0.74)[[0.134]$ & $0.23(0.82)[[0.059]$ & $0.36(0.72)[[0.164]$ \\
\hline 06464100 & $-0.21(0.83)[-0.002]$ & $0.34(0.73)[[0.022]$ & $-0.11(0.91)[-0.003]$ & $0.62(0.53)[[0.016]$ \\
\hline
\end{tabular}




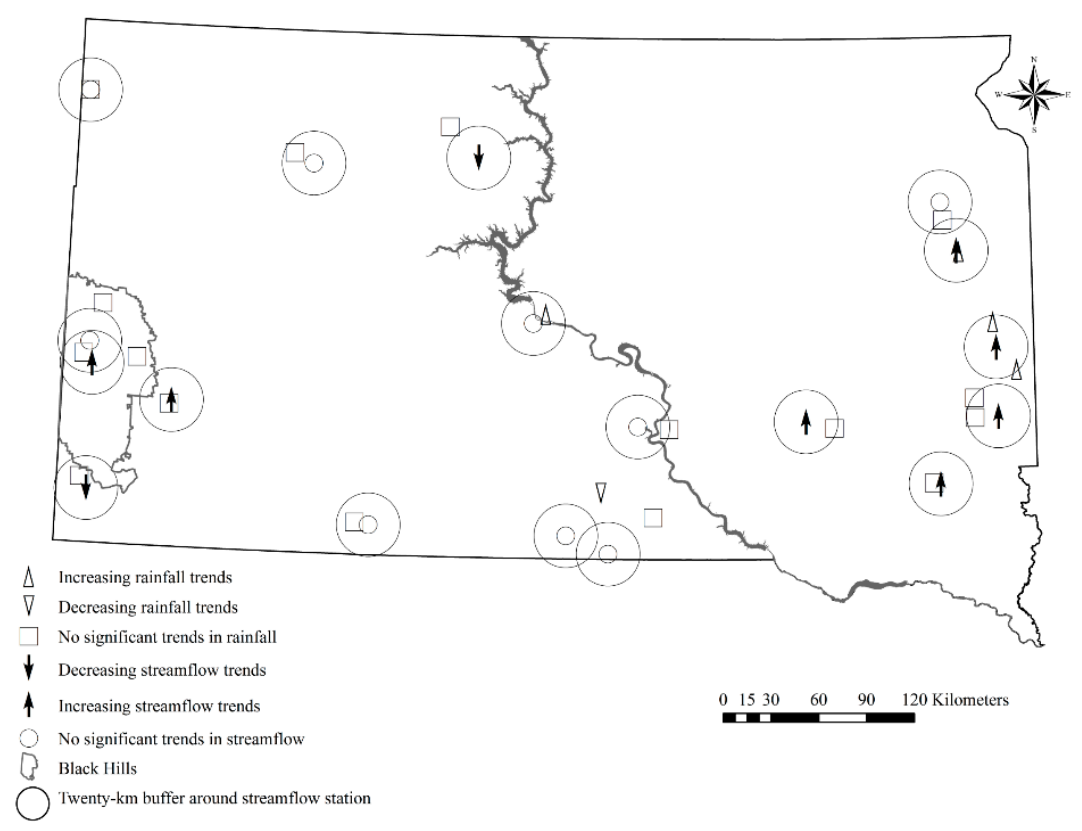

Figure 2. Trends in annual streamflow and rainfall in South Dakota.

In western SD, all the streamflow gauging stations with increasing trends in annual streamflow (17\% of western streams) were located in the Black Hills region (Figure 2). Similar findings were reported by Miller and Driscoll [69] who also found that annual streamflow has increased in the Black Hills region over a period of 1904 to 1993. These trends may be the effects of climate due to increases in rainfall in the Black Hills $[69,70]$. Eighty-three percent of the streams located in the east showed significant increasing trends (Figure 2), suggesting that the eastern side of the state is getting wetter. This tendency of increasing streamflow may be the result of increasing rainfall in the east over the study period (see discussion on rainfall below). Over the 63-year study period i.e., 1951 to 2013), about $50 \%$ of the studied streams showed significant increasing trends in annual one-day minimum and seven-day minimum flows (Table 2; Figure 3), indicating that baseflow is rising in these specific watersheds. Increasing low flow may be due to land use change as in a similar case reported by Zhang and Schilling [14] for Ohio watersheds. Other studies also reported increased low flows for streams in the Midwest region such as rivers in Iowa and Ohio $[14,15,39,71]$. Land use change can also contribute to an increase or decrease in low flow conditions. For example, Sikka et al. [72] found that conversion of natural grassland to bluegum plantation in the Nilgiris watershed in southern India resulted in decreased low flow. In the present study, there were no decreasing trends in low flow in the study watersheds. In eastern SD, 34\% of the streams showed significant increasing trends in both one-day minimum and seven-day minimum flows, whereas in western SD, $17 \%$ and $12 \%$ streams showed significant increasing trends in one-day minimum and seven-day minimum flows, respectively (Figure 3). 

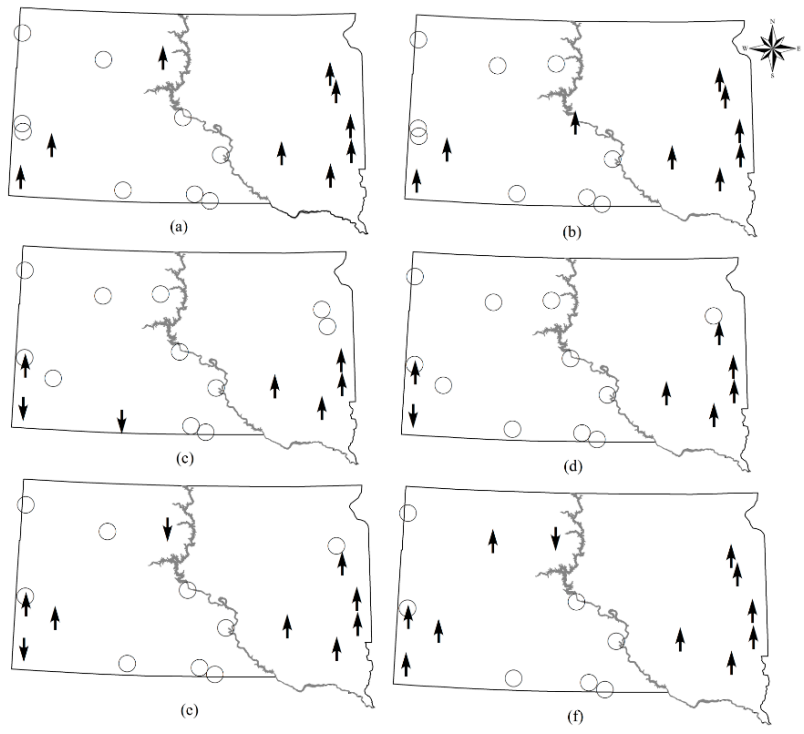

$\downarrow$ Significant decreasing trends

$\uparrow$ Significant increasing trends

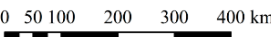

No trends

Figure 3. Spatial distribution of streamflow gauging stations with statistical significant and no trends in (a) one-day minimum flow; (b) seven-day minimum flow; (c) one-day maximum flow; (d) seven-day maximum flow; (e) daily average flow; and (f) median daily flow.

Analysis of moderate flow statistics showed significant increasing trends in $56 \%$ of the studied streams for median daily flow, while 39\% showed significant increasing trends in daily average flow. According to Norton et al. [40], daily average streamflow increased, mainly, in the eastern part of the Missouri River Basin (SD, North Dakota, Iowa, and Nebraska), while decreasing streamflow was observed in its western parts, covering Montana and Wyoming. Seasonally, moderate flow statistics i.e., median daily flow, daily average flow) revealed that more than $50 \%$ of the streams had increasing trends in fall ( $67 \%$ for median daily flow and $50 \%$ for daily average flow) and winter ( $56 \%$ for median daily flow and $62 \%$ for daily average flow) compared to spring ( $45 \%$ and $34 \%$ for median daily and daily average flows, respectively) and summer seasons (39\% and $34 \%$ for median daily and daily average flows, respectively) (Tables 2 and 3; Figure 3), suggesting that daily average flow in SD streams are increasing, especially in fall and winter. These results are consistent with seasonal streamflow trend analyses reported by Lins and Slack [39] and Karl and Knight [73] for the conterminous United States, where moderate flows increased in fall and winter seasons between the years of 1910 to 1996 for most regions. In eastern SD, $28 \%$ and $34 \%$ of the studied streams showed significant increasing trends in daily average flow and median daily flows, compared to western SD, where $12 \%$ and $23 \%$ of the streams showed significant increasing trends, respectively (Figure 3).

The number of streams with significant increasing trends for high flow statistics was low compared to low flow and moderate flow statistics. Five streams (28\%) have increasing trends in annual one-day maximum streamflow while six streams (33\%) show significant increasing trends in seven-day maximum streamflow (Table 2; Figures 3 and 4). The increasing trend in high flows in these streams is likely due to increasing extreme or more frequent rainfall events or increased runoff during snowmelt. Twelve percent and $6 \%$ of the studied streams showed significant decreasing trends in one-day maximum and seven-day maximum flows, respectively. High flows were also noticed in Iowa due to climate change and agricultural and urban land use expansion [74]. Sixty-seven and $83 \%$ of the studied eastern streamflow gauging stations showed significant increasing trends in one-day maximum and seven-day maximum flows, whereas $8 \%$ of western watersheds showed significant increasing trends in both high flow statistics (Figure 3). These results also suggest that the eastern side of the state will likely have, over time, high flow activities such as flooding and erosion. The number of streams with significant increasing trends in high flow conditions were the least among all three flow 
conditions i.e., low, moderate, and high flow conditions) in SD watersheds. Similar findings were concluded by McCabe and Wolock [75] and Kumar et al. [25] in the eastern United States and Indiana, respectively. McCabe \& Wolock [75] reported that most changes in streamflow statistics occurred in annual minimum and median daily streamflow compared to high flow statistics. Kumar et al. [25] also found that most streams in Indiana showed significant increasing trends in low flow conditions more than in high flow conditions.

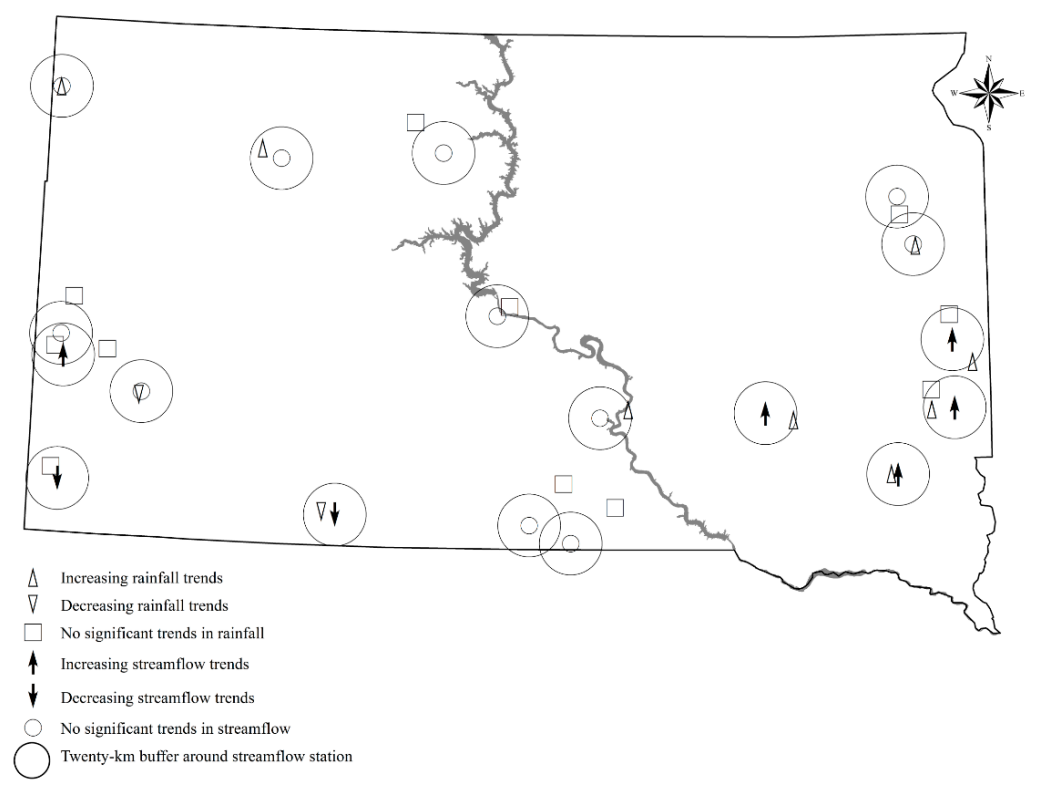

Figure 4. Trends in one-day maximum streamflow and rainfall in South Dakota.

Trend magnitude was assessed for annual streamflow and presented in Table 2. Increasing trend magnitude varied from $0.02 \mathrm{~mm} /$ year at station 06464100 to $0.68 \mathrm{~mm} /$ year at station 06478690 (Table 2), while decreasing trend magnitude varied from $0.03 \mathrm{~mm} /$ year to $0.4 \mathrm{~mm} /$ year (Table 2). Seasonal trend magnitude was greater in spring than in fall, summer, and winter seasons for more than $50 \%$ of the studied streams. High trend magnitude was also reported for spring flows in eastern North America [76]. While trend magnitude for seasonal streamflow was high in spring at a majority of the studied streamflow gauging stations, the actual streamflow trends increased in fall and winter seasons compared to other seasons. This means that spring flows may consistently have high flows but these flows may not be increasing over time in contrast to flows in other seasons.

Unlike streamflow, annual rainfall did not show significant increasing trends at a majority of the studied rainfall gauging stations. Out of 21 rainfall stations, only four stations (19\%, Pierre Regional Airport, Brookings 2 NE, Flandreau and Castlewood) showed significant increasing trends, and one station (5\%, Winner, SD) showed a significant decreasing trend (Table 4; Figure 2). Previous studies showed that the central Great Plains region (e.g., Kansas, Nebraska, and Oklahoma) experienced increases in rainfall between 1981 and 2001 [65]. Seasonal rainfall followed the same pattern as seasonal streamflow across the state (Table 5). Rainfall stations with increasing rainfall are significantly higher in fall and winter (24\% in both seasons) than in spring $(10 \%)$ and summer seasons $(5 \%)$. Other studies conducted in the Midwest region also reported similar seasonal patterns for rainfall trends. Karl \& Knight [73], for example, reported that rainfall increased in the conterminous U.S. in fall compared to other seasons from 1910 to 1996 [75]. Similarly, a study by Small et al. [77] revealed a statistically significant trend in fall precipitation in the Upper Mississippi River watershed between 1948 and 1997. All rainfall gauging stations with significant increasing trends, which constitute $19 \%$ of the total stations, were located in eastern side of the state, while one station with significant decreasing trends is located in western SD. 
Table 4. Annual rainfall trends and trend magnitudes in South Dakota. Modified Mann-Kendall Z-value, ( $p$-value) and [magnitude, $\mathrm{mm} /$ year] are shown. Values in bold represent statistical significant trends at $90 \%$ confidence level.

\begin{tabular}{|c|c|c|}
\hline Rainfall Gauging Station Number & Annual Rainfall & One-Day Maximum Rainfall \\
\hline GHCND: USC00398528 & $-1.13(0.26)[-2.35]$ & $1.64(0.09)$ \\
\hline GHCND: USC00392557 & $-0.74(0.46)[-0.59]$ & $0.53(0.59)$ \\
\hline GHCND: USC00392228 & $0.00(0.99)[4.02]$ & $0.84(0.40)$ \\
\hline GHCND:USW00024025 & $1.73(0.08)[0.94]$ & $0.09(0.92)$ \\
\hline GHCND: USC00391609 & $0.71(0.48)[1.48]$ & $1.76(0.08)$ \\
\hline GHCND: USC00393452 & $1.55(0.12)[1.85]$ & $1.54(0.12)$ \\
\hline GHCND: USC00391851 & $-1.53(0.12)[-4.56]$ & $2.02(0.04)$ \\
\hline GHCND: USC00391634 & $-0.69(0.49)[-3.50]$ & $0.61(0.54)$ \\
\hline GHCND: USC00393775 & $1.17(0.24)[1.53]$ & $-2.12(0.03)$ \\
\hline GHCND: USC00398307 & $0.94(0.35)[0.64]$ & $-0.96(0.34)$ \\
\hline GHCND: USC00395671 & $1.30(0.19)[1.63]$ & $1.79(0.07)$ \\
\hline GHCND: USC00395228 & $0.52(0.60)[0.58]$ & $1.71(0.08)$ \\
\hline GHCND: USC00391294 & $1.04(0.30)[1.15]$ & $1.62(0.09)$ \\
\hline GHCND: USC00395281 & $1.24(0.21)[1.68]$ & $-4.26(<0.10)$ \\
\hline GHCND: USC00391076 & $1.63(0.10)[1.25]$ & $1.43(0.15)$ \\
\hline GHCND: USC00392984 & $1.74(0.08)[2.61]$ & $2.16(0.03)$ \\
\hline GHCND: USC00391519 & $2.01(0.04)[1.55]$ & $2.00(0.04)$ \\
\hline GHCND: USW00014946 & $-0.25(0.80)[-0.38]$ & $0.91(0.36)$ \\
\hline GHCND: USC00396427 & $-0.64(0.52)[-0.83]$ & $1.47(0.14)$ \\
\hline GHCND: USC00394834 & $1.55(0.12)[4.48]$ & $1.07(0.28)$ \\
\hline GHCND: USC00399367 & $-1.74(0.08)[-3.62]$ & $-0.87(0.38)$ \\
\hline
\end{tabular}

Table 5. Seasonal rainfall trends and trend magnitudes in South Dakota. Modified Mann-Kendall Z-value, ( $p$-value) and [magnitude, $\mathrm{mm} /$ year] are shown. Values in bold represent statistical significant trends at $90 \%$ confidence level.

\begin{tabular}{|c|c|c|c|c|}
\hline Rainfall Station & Fall & Spring & Summer & Winter \\
\hline GHCND: USC00398528 & $-0.58(0.56)[-0.16]$ & $-1.57(0.11)[-0.81]$ & $-1.08(0.28)[-0.59]$ & $-2.16(0.03)[-0.31]$ \\
\hline GHCND: USC00392557 & $-0.045(0.96)[-0.02]$ & $0.14(0.89)[0.06]$ & $-2.00(0.05)[-0.94]$ & $0.48(0.63)[0.12]$ \\
\hline GHCND: USC00392228 & $0(1.00)[-0.12]$ & $-0.25(0.80)[-0.30]$ & $0.80(0.42)[0.81]$ & $2.42(0.02)[1.49]$ \\
\hline GHCND:USW00024025 & $0(1.00)[0.87]$ & $1.64(0.09)[0.28]$ & $-0.42(0.67)[-0.14]$ & $-0.54(0.59)[-0.11]$ \\
\hline GHCND: USC00391609 & $-0.08(0.934)[-0.8]$ & $-1.53(0.13)[-0.91]$ & $1.06(0.29)[0.87)$ & $1.79(0.07)[0.38]$ \\
\hline GHCND: USC00393452 & $1.34(0.18)[1.57]$ & $-1.31(0.19)[-1.62]$ & $1.76(0.08)[1.90]$ & $0.62(0.54)[0.22]$ \\
\hline GHCND: USC00391851 & $-1.21(0.23)[-0.8]$ & $-1.15(0.25)[-1.14]$ & $-1.55(0.12)[-2.52]$ & $0.02(0.98)[0.02]$ \\
\hline GHCND: USC00391634 & $-0.693(0.49)[-1.53]$ & $0.00(1.00)[-0.04]$ & $-0.52(0.60)[-0.76]$ & $-1.40(0.16)[-1.26]$ \\
\hline GHCND: USC00393775 & $1.392(0.16)[0.46]$ & $1.19(0.23)[1.73]$ & $0.24(0.81)[1.73]$ & $-0.21(0.83)[-0.02]$ \\
\hline GHCND: USC00398307 & $1.493(0.14)[0.47]$ & $-0.65(0.52)[-0.26]$ & $0.21(0.83)[0.07]$ & $1.89(0.06)[0.22]$ \\
\hline GHCND: USC00395671 & $1.79(0.07)[1.18]$ & $1.15(0.25)[0.64]$ & $-1.60(0.11)[-0.70]$ & $1.13(0.26)[0.14]$ \\
\hline GHCND: USC00395228 & $-1.168(0.24)[-0.31]$ & $1.48(0.14)[0.64]$ & $0.00(1.00)[-0.01]$ & $0.17(0.86)[0.05]$ \\
\hline GHCND: USC00391294 & $1.33(0.18)[0.08]$ & $1.28(0.20)[0.08]$ & $0.46(0.64)[0.22]$ & $0.61(0.54)[0.07]$ \\
\hline GHCND: USC00395281 & $2.02(0.02)[0.85]$ & $0.47(0.64)[0.23]$ & $-0.25(0.80)[-0.36]$ & $1.86(0.06)[0.30]$ \\
\hline GHCND: USC00391076 & $1.19(0.23)[0.79]$ & $1.84(0.07)[0.73]$ & $0.04(0.96)[0.01]$ & $1.31(0.19)[0.27]$ \\
\hline GHCND: USC00392984 & $2.18(0.03)[1.40]$ & $1.36(0.17)[0.61]$ & $1.07(0.29)[0.58]$ & $0.21(0.83)[0.05]$ \\
\hline GHCND: USC00391519 & $1.85(0.06)[0.88]$ & $0.77(0.44)[0.16]$ & $0.12(0.90)[0.03]$ & $-0.98(0.33)[-0.07]$ \\
\hline GHCND: USW00014946 & $2.92(<0.10)[0.86]$ & $-0.49(0.63)[-0.23]$ & $-1.28(0.20)[-0.48]$ & $0.28(0.78)[0.08]$ \\
\hline GHCND: USC00396427 & $-1.66(0.09)[-0.84]$ & $1.33(0.18)[1.19]$ & $-1.22(0.22)[-1.15]$ & $1.03(0.30)[0.16]$ \\
\hline GHCND: USC00394834 & $0.709(0.48)[0.50]$ & $0.49(0.62)[0.75]$ & $0.79(0.43)[0.76]$ & $1.89(0.06)[1.74]$ \\
\hline GHCND: USC00399367 & $-1.544(0.12)[-1.13]$ & $-1.59(0.11)[-1.64]$ & $-1.64(0.09)[-2.36]$ & $0.95(0.34)[-0.31]$ \\
\hline
\end{tabular}

The number of rainfall stations with significant trends in one-day maximum rainfall was greater than the number of stations with significant trends in annual rainfall (Table 4). Similar to one-day maximum streamflow, one-day maximum rainfall increased over the study period at $38 \%$ of rainfall gauging stations (Figure 4; Table 4). In the east, $29 \%$ of total statewide stations have significant increasing trends in one-day maximum rainfall, while $10 \%$ of rainfall gauging stations have significant increasing trends in the west (Figure 4). There were no significant decreasing trends in one-day 
maximum rainfall in eastern $\mathrm{SD}$, while $10 \%$ of rainfall gauging stations had significant decreasing trends in the west over the study period (Figure 4).

Rainfall stations that fall in the same buffer exhibited varying trends with decreasing and increasing trends in annual rainfall. Only two streamflow stations contain more than one rainfall station in their corresponding buffers (Figure 2). The Big Sioux River station near Dell Rapid has two rainfall stations, which are Colton and Chester stations. While annual rainfall slightly decreased at the two rainfall stations around Dell Rapid streamflow station, one-day maximum rainfall showed increasing trends in both rainfall stations, with a significant increasing trend at Colton and a slight increasing at the Chester station. The Big Sioux River streamflow station near Brookings also has two rainfall observation stations (Brookings $2 \mathrm{NE}$ and Flandreau), which showed significant increasing trends for annual rainfall. However, slight increasing and significant increasing trends were observed in one-day maximum rainfall at Brookings $2 \mathrm{NE}$ and Flandreau station, respectively.

The magnitude of increasing trends in annual rainfall ranged between $0.58 \mathrm{~mm} /$ year (at Marion, SD station) to $4.48 \mathrm{~mm} /$ year (at Lead, SD station) (Table 4). The magnitude of decreasing trends in annual rainfall ranged between $0.38 \mathrm{~mm}$ per year (at Watertown Regional Airport station) to $4.6 \mathrm{~mm} /$ year (at Colton, SD station) (Table 4). There was no specific pattern in seasonal rainfall magnitude in the state (Table 5).

Visual inspection of streamflow time series (e.g., Figure 5) and statistical analysis (Figure 2) showed that $100 \%$ of streamflow stations and $70 \%$ of rainfall stations in the east, and $83 \%$ of streamflow stations along with $64 \%$ of rainfall stations in the west exhibited significant and slight increasing trends, suggesting that rainfall may likely be a major contributing factor to streamflow trends in the studied watersheds. However, within the buffer zones (see Figure 1), trends in streamflow i.e., statistically significant trends) correspond to trends in annual rainfall at $11 \%$ of the studied streamflow gauging stations for annual streamflow and $28 \%$ for one-day maximum streamflow across the state (Figures 2 and 4). Overall, both streamflow and rainfall significantly or slightly increased over time in the majority of studied watersheds in eastern SD compared to western SD.

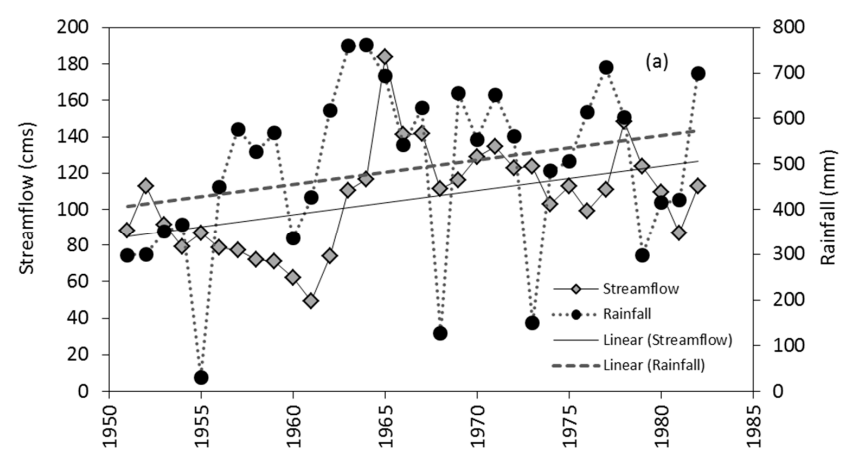

(a)

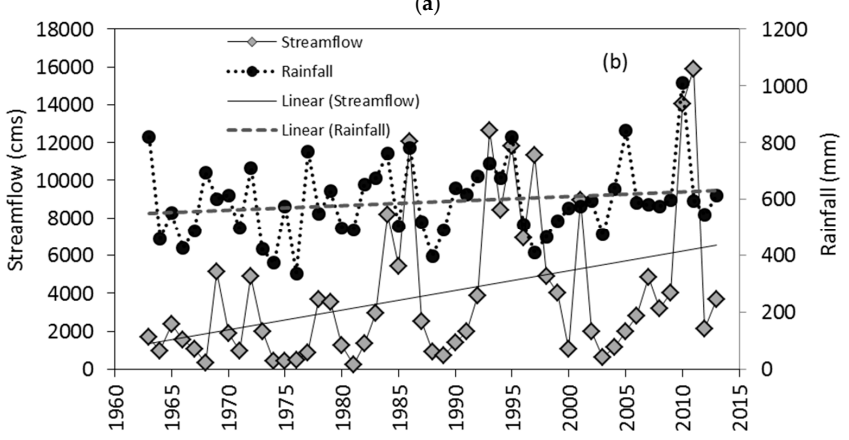

(b)

Figure 5. Streamflow and rainfall time series for case SG4 in the west (a) and SG17 in the east (b) (see Figure 1 and Table 1). SG4 and SG17 are respectively Castle Creek near Deerfield Res and Hill City, and Big Sioux River near Brookings, South Dakota. 


\subsection{Elasticity of Streamflow to Rainfall and Change in Grassland Area}

To assess the impacts of climate variability and grassland cover change on streamflow, rainfall and grassland cover change elasticity coefficients were calculated using Equations (9) and (10). The analysis indicates that $62 \%$ of the computed rainfall elasticity coefficients varied between 1.0 and 3.0, suggesting that a $1 \%$ annual rainfall increase would result in more than a $1 \%$ annual streamflow increase. In $28 \%$ of the studied streams i.e., five streams), rainfall elasticity coefficients were less than 1.0, indicating that rainfall did not significantly affect variation in annual streamflow over the study period. As shown in Figure 6, for two watersheds, rainfall elasticity coefficients were -0.18 (at station 06464100) and -1.54 (at station 06360500), respectively. These results suggest that a $10 \%$ increase in annual rainfall would lead to $1.8 \%$ and $15 \%$ drops in annual streamflow in these watersheds. The decrease in annual streamflow may be explained by increased evaporation losses due to temperature increase $[61,78,79]$ as South Dakota experienced temperature increases in the last century [68] with potential effects on streamflow response in the state [79].

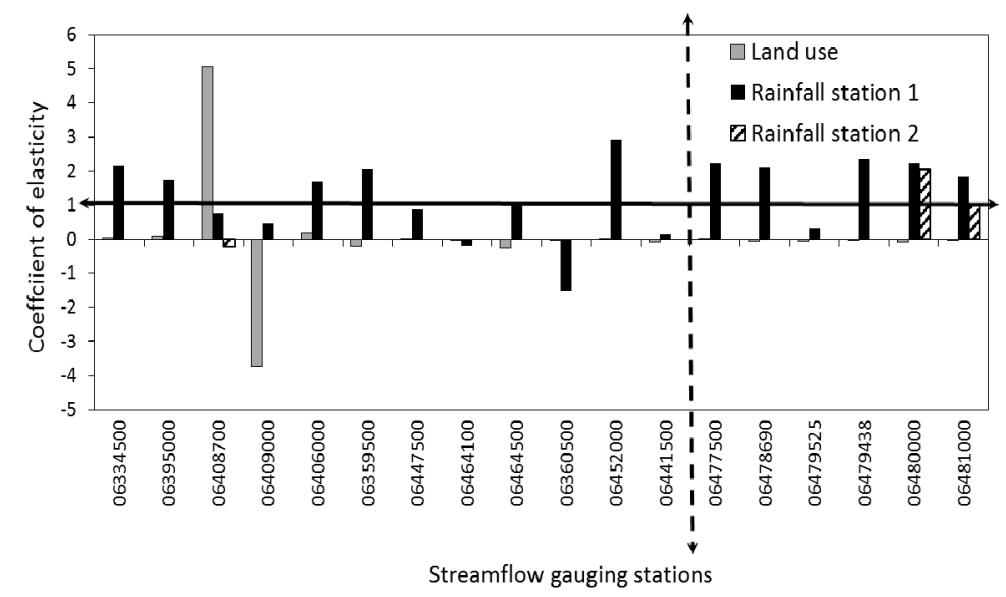

Figure 6. Streamflow elasticity to rainfall and change in grassland area in South Dakota watersheds. The dash line represents the Missouri River, which bisects the state into west and east.

In comparison with climate elasticity analysis, elasticity of streamflow to change in grassland area was not significant in most study watersheds. Annual streamflow was highly elastic to change in grassland area with coefficients of 5.07 and -3.72 , respectively, in only two watersheds (stations 06408700 and 06409000 ) out of 18 (Figure 6). The elasticity coefficients of 5.07 and -3.72 indicate that $10 \%$ increase in grassland area would cause $50 \%$ increase and $37 \%$ decrease in annual streamflow, respectively [61]. In both watersheds, the percentage of grassland was low (less than $18 \%$ of watershed area) compared to the remaining watersheds, which have more than $30 \%$ of their watershed area in grassland. Grassland losses in the two watersheds during the study period was very rapid (17\% and 7\%, respectively, in 1951 to $7 \%$ and $2 \%$ in 2011), suggesting that grassland losses may be the primary cause of variation in streamflow in the two watersheds as grasslands influence infiltration capability of soil [80]. Soil infiltration capacity was shown to be greater in grassland compared to cropland [80] and grassland can reduce overland flow by $20 \%$ in comparison with cropland [81]. The negative coefficient of elasticity (-3.72; Figure 6) at the Castle Creek station (06409000) indicates that a decrease in grassland cover may cause an increased streamflow in the watershed (Figures 5 and 7). The rapid change in grassland area likely influenced Castle Creek's water yield, even though the rainfall gauging station (Deerfield 4 NW) near Castle Creek showed increasing trends in rainfall (Figures 2 and 5 Table 4). Grassland conversion to cropland, predominantly to corn, in the watershed draining into this stream, may have decreased ET, increased surface runoff, and increased water yield as shown by Schilling et al. [15]. At station 06408700 i.e., Rhoads Fork), the change in grassland area and streamflow trends are in the same direction i.e., positive elasticity 
coefficient; Figures 5-7; Table 2). This could be explained by the absence of appropriate rainfall for agricultural activities due to drought events reported for the Rhoads Fork watershed between 1982 and 2009 [82], combined with the rapid change in grassland cover. In the absence of climate component i.e., rainfall), available water in the watershed will decrease, causing ET to decrease and water yield to decrease, suggesting that grassland cover may have been the dominant driving factor in streamflow trends in this particular watershed. Thus, depletion of grassland cover would result in water yield decreased in Rhoads Fork watershed. However, the analysis conducted in this study did not isolate the individual contributions of rainfall and grassland area to draw definite conclusions. In the remaining $16(89 \%)$ studied watersheds, elasticity coefficients were less than 1 , which indicates that grassland area change did not have pronounced influence in the variation of annual streamflow over the study period (Figure 6).
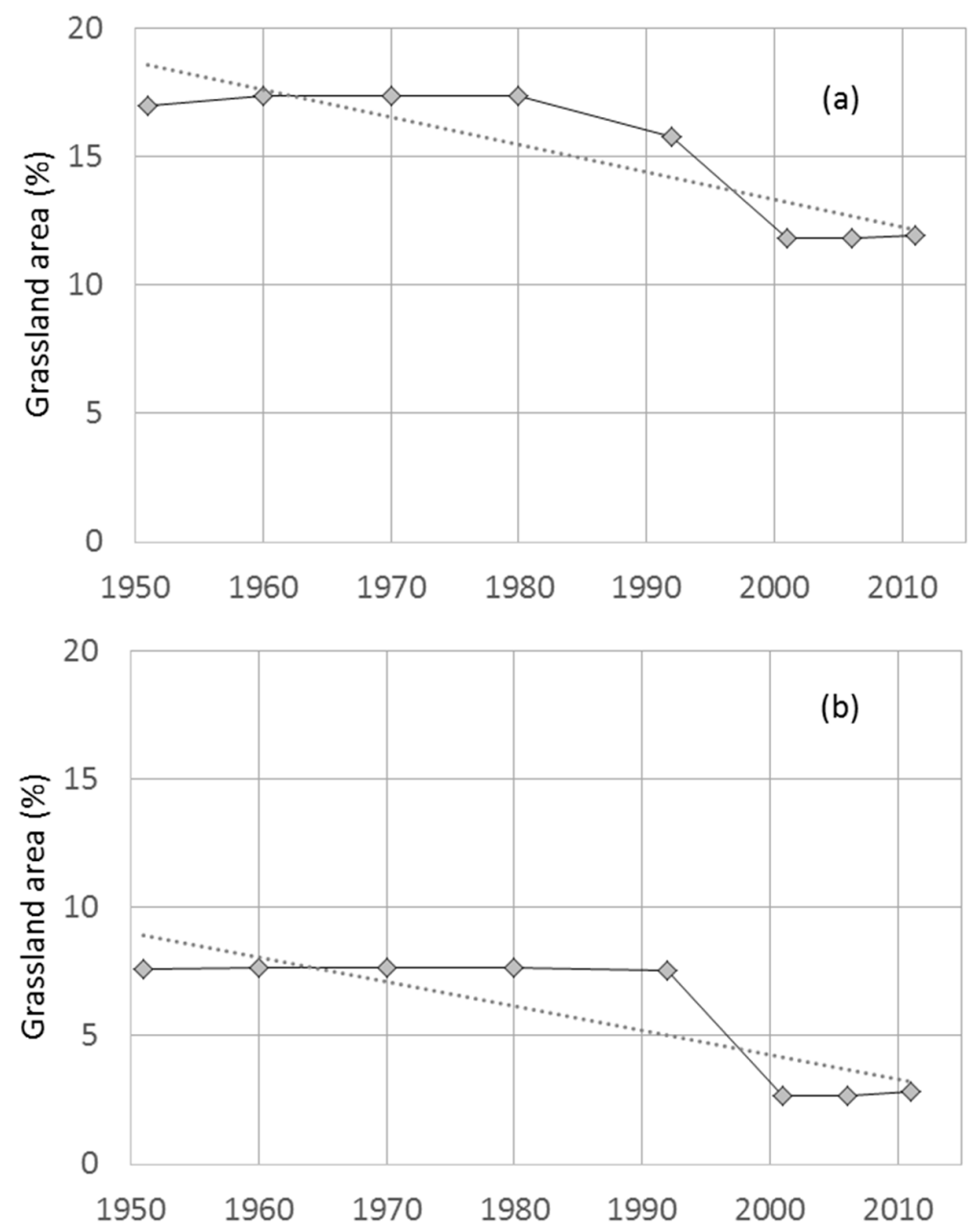

Figure 7. Change in grassland area from 1951 to 2011 (a) in Castle Creek near Deerfield Res and Hill City (Case SG4); and (b) Rhoads Fork near Rochford (Case SG3) watersheds. The two cases are the western watersheds with a rapid decrease in grassland area after 1990.

In this analysis, streamflow elasticity to rainfall and grassland area varied spatially across the state. It appears that streamflow is highly influenced by rainfall in eastern SD ( $84 \%$ of eastern watersheds) (Figure 6), while annual streamflow in $59 \%$ of western watersheds showed high elasticity to annual rainfall. Streamflow was significantly elastic to grassland area change in two out of 12 western watersheds but was not noticeable elastic to change in grassland area in eastern watersheds. Overall, the elasticity analysis revealed that rainfall explains most variations in annual streamflow across the state, with more than $50 \%$ of the streams having elasticity coefficients greater than 1 between 
streamflow and rainfall (Figure 6). Results from this study are comparable to other similar studies conducted for the Midwest region (including watersheds in Indiana, Illinois, Ohio, and Iowa [19]), where streamflow was shown to be elastic to rainfall $[19,62]$.

\section{Conclusions}

Long-term data from 18 streamflow and 21 rainfall observation stations were analyzed for trends using a modified Mann-Kendall test. Impacts of climate variability and land use change i.e., grassland) on streamflow were also examined using streamflow elasticity concept. Results from the trend analysis showed that annual streamflow exhibited significant upward trends in 39\% of the studied streams, of which $28 \%$ are in the east and $11 \%$ are in the west. The remaining $61 \%$ streams showed increasing trends $(50 \%)$ and significant decreasing trends $(11 \%)$. The increasing trends were more significant in moderate flow conditions i.e., median daily and daily average flows) compared to low flow and high flow conditions. There were significant increasing trends in 39\% for daily average flow and $56 \%$ of the streams for median daily flow. Low flows (one-day minimum flow and seven-day minimum flow) showed significant upward trends in $50 \%$ of the studied streams, suggesting increasing baseflow in the state. The number of streams with significant increasing trends was less for high flow conditions $(28 \%$ in one-day maximum flow; $34 \%$ in seven-day maximum flow). Analysis of seasonal flows showed $56 \%$ of streams with significant upward trends in fall and $62 \%$ in winter. Less than $35 \%$ of the studied streams showed significant upward trends in spring and summer ( $23 \%$ and $34 \%$, respectively). Most of the stations with significant increasing trends were clustered in eastern SD for all flow conditions i.e., annual, low, moderate, and high flow conditions).

Annual rainfall exhibited significant increasing trends at 19\% of rainfall gauging stations, which are all located in the eastern part of the state. Forty-eight percent of rainfall gauging stations showed slight upward trends, 5\% exhibited significant downward trends, and 29\% showed slight downward trends. Trends in seasonal rainfall showed similar patterns as seasonal streamflow, with $48 \%$ of significant increasing trends in fall and winter seasons across the state. Upward trends for one-day maximum rainfall trends increased over the study period (38\%) compared to annual rainfall increasing trends (29\% in the east and $10 \%$ in the west). Of the remaining rainfall stations, $43 \%$ showed slight increasing trends, $10 \%$ showed slight decreasing trends and 10\% showed significant decreasing trends.

During the study period (1951-2013), the elasticity of streamflow revealed that streamflow was more sensitive to variation in rainfall than changes in grassland area across the state, except in two watersheds located in western SD, where variation in streamflow was more sensitive to rapid loss in grassland area. Rainfall had a greater effect on streamflow in eastern watersheds compared to western watersheds.

While this study suggests that climate variability likely affects streamflow trends in the state over the study period, sustainable management of water resources needs careful consideration of all climatic and anthropogenic driving factors, which can be further examined and explored in future studies. A comprehensive assessment of streamflow response to all climatic variables such as snowfall, temperature, and ET would add to understanding of the effects of climate on hydrological response. In this study, rainfall stations were chosen within 20-km buffer of streamflow gauging stations with the assumption that they accurately represent rainfall in the study watersheds, regardless of their proximity to the stream gauging stations. In large watersheds, it is possible that rainfall in upper parts of the watershed may contribute more to streamflow than the closest precipitation station. Further studies should consider selecting rainfall stations in locations that will likely influence streamflow within the watersheds. Better land use maps with annual time series estimates of grassland area could also provide more accurate assessment of grassland impacts on hydrology. The spatial extent at which land use would start to affect streamflow response was not investigated in this study; but would certainly increase understanding of streamflow response to land use change. The results presented in this study provides a useful groundwork for additional research on climate and land use change in SD. 
Results would also help policy makers and watershed managers for better planning and management of water resources in SD.

Acknowledgments: The authors acknowledge financial support from the United States Department of Agriculture-National Institute of Food and Agriculture; Hatch Project No. SD00H542-15.

Author Contributions: Karishma Kibria conducted this study as part of her Master's Thesis under the guidance of Laurent Ahiablame. She wrote the initial draft of the manuscript. Laurent Ahiablame developed the research idea, supervised and guided this work. He edited and improved the manuscript. Chris Hay served as a member of Karishma Kibria's graduate committee. He helped with summarization and interpretation of results and reviewed the manuscript. Gemechis Djira served as a member of Karishma Kibria's graduate committee and wrote R codes used for the statistical analyses. He provided guidance related to his expertise and reviewed the manuscript.

Conflicts of Interest: The authors declare no conflict of interest.

\section{References}

1. Samson, F.B.; Knopf, F.L.; Ostlie, W.R. Great plains ecosystems: Past, present, and future. Wildl. Soc. Bull. 2004, 32, 6-15. [CrossRef]

2. Reitsma, K.D.; Dunn, B.H.; Smart, A.J.; Clay, S.A.; Carlson, C.G. Estimated South Dakota Land Use Change from 2006 to 2012; SDSU Department of Plant Science, SDSU Extension: Brookings, SD, USA, 2013.

3. Wright, C.K.; Wimberly, M.C. Recent land use change in the western corn belt threatens grasslands and wetlands. Proc. Natl. Acad. Sci. USA. 2013, 110, 4134-4139. [CrossRef] [PubMed]

4. Rosentrater, K.A.; Todey, D.; Persyn, R. Quantifying total and sustainable agricultural biomass resources in South Dakota-A preliminary assessment. Agric. Eng. Int. 2009, 11, 1-14.

5. Olson, A.L.; Klein, N.; Taylor, G. The Impact of Increased Ethanol Production on Corn Basis in South Dakota. Ph.D. Thesis, South Dakota State University, Brookings, SD, USA, 2007.

6. Schmer, M.R.; Dose, H.L. Cob biomass supply for combined heat and power and biofuel in the north central USA. Biomass Bioenergy 2014, 64, 321-328. [CrossRef]

7. United States Congress-Senate. Energy Independence and Security Act of 2007. HR 6. 110th Congress, 1st Session. Available online: https://www.govtrack.us/congress/bills/110/hr2304 (accessed on 23 December 2015).

8. Altieri, M.A. The ecological impacts of large-scale agrofuel monoculture production systems in the americas. Bull. Sci. Technol. Soc. 2009, 29, 236-244. [CrossRef]

9. Lüscher, A. Land use systems in grassland dominated regions. In Proceedings of the 20th general meeting of the European grassland federation, Luzern, Switzerland, 21-24 June 2004.

10. Boval, M.; Dixon, R. The importance of grasslands for animal production and other functions: A review on management and methodological progress in the tropics. Animal 2012, 6, 748-762. [CrossRef] [PubMed]

11. Carlier, L.; Rotar, I.; Vlahova, M.; Vidican, R. Importance and functions of grasslands. Not. Bot. Horti Agrobot. 2009, 37, 25-30.

12. Claassen, R.; Carriazo, F.; Cooper, J.C.; Hellerstein, D.; Ueda, K. Grassland to Cropland Conversion in the Northern Plains: The Role of Crop Insurance, Commodity, and Disaster Programs; Economic Research Service, U.S Department of Agriculture: Washington DC, USA, 2011.

13. Schilling, K.E.; Chan, K.-S.; Liu, H.; Zhang, Y.-K. Quantifying the effect of land use land cover change on increasing discharge in the Upper Mississippi River. J. Hydrol. 2010, 387, 343-345. [CrossRef]

14. Zhang, Y.-K.; Schilling, K. Increasing streamflow and baseflow in Mississippi River since the 1940s: Effect of land use change. J. Hydrol. 2006, 324, 412-422. [CrossRef]

15. Schilling, K.E.; Jha, M.K.; Zhang, Y.K.; Gassman, P.W.; Wolter, C.F. Impact of land use and land cover change on the water balance of a large agricultural watershed: Historical effects and future directions. Water Resour. Res. 2008. [CrossRef]

16. Huntington, T.G. Evidence for intensification of the global water cycle: Review and synthesis. J. Hydrol. 2006, 319, 83-95. [CrossRef]

17. Tan, M.L.; Ibrahim, A.L.; Yusop, Z.; Duan, Z.; Ling, L. Impacts of land-use and climate variability on hydrological components in the Johor river basin, Malaysia. Hydrol. Sci. J. 2015, 60, 873-889. [CrossRef]

18. Wei, X.; Liu, W.; Zhou, P. Quantifying the relative contributions of forest change and climatic variability to hydrology in large watersheds: A critical review of research methods. Water 2013, 5, 728-746. [CrossRef] 
19. Xu, X.; Scanlon, B.R.; Schilling, K.; Sun, A. Relative importance of climate and land surface changes on hydrologic changes in the US Midwest since the 1930s: Implications for biofuel production. J. Hydrol. 2013, 497, 110-120. [CrossRef]

20. Nejadhashemi, A.; Wardynski, B.; Munoz, J. Evaluating the impacts of land use changes on hydrologic responses in the agricultural regions of Michigan and Wisconsin. Hydrol. Earth Syst. Sci. Discuss. 2011, 8, 3421-3468. [CrossRef]

21. Fitzpatrick, F.A.; Knox, J.C.; Whitman, H.E. Effects of Historical Land-Cover Changes on Flooding and Sedimentation, North Fish Creek, Wisconsin; US Department of the Interior, US Geological Survey: Middleton, WI, USA, 1999.

22. Frans, C.; Istanbulluoglu, E.; Mishra, V.; Munoz-Arriola, F.; Lettenmaier, D.P. Are climatic or land cover changes the dominant cause of runoff trends in the Upper Mississippi River Basin? Geophys. Res. Lett. 2013, 40, 1104-1110. [CrossRef]

23. Hu, Z.; Wang, L.; Wang, Z.; Hong, Y.; Zheng, H. Quantitative assessment of climate and human impacts on surface water resources in a typical semi-arid watershed in the middle reaches of the Yellow River from 1985 to 2006. Int. J. Climatol. 2015, 35, 97-113. [CrossRef]

24. Kim, J.; Choi, J.; Choi, C.; Park, S. Impacts of changes in climate and land use/land cover under ipcc rcp scenarios on streamflow in the Hoeya River Basin, Korea. Sci. Total Environ. 2013, 452, 181-195. [CrossRef] [PubMed]

25. Kumar, S.; Merwade, V.; Kam, J.; Thurner, K. Streamflow trends in Indiana: Effects of long term persistence, precipitation and subsurface drains. J. Hydrol. 2009, 374, 171-183. [CrossRef]

26. Novotny, E.V.; Stefan, H.G. Stream flow in Minnesota: Indicator of climate change. J. Hydrol. 2007, 334, 319-333. [CrossRef]

27. Vogel, R.M. Hydromorphology. J. Water Resour. Plan. Manag. 2011, 137, 147-149. [CrossRef]

28. Wang, D.; Hejazi, M. Quantifying the relative contribution of the climate and direct human impacts on mean annual streamflow in the contiguous United States. Water Resour. Res. 2011. [CrossRef]

29. Yang, Z.F.; Yan, Y.; Liu, Q. The relationship of streamflow-precipitation-temperature in the Yellow River Basin of China during 1961-2000. Procedia Environ. Sci. 2012, 13, 2336-2345. [CrossRef]

30. Adam, J.C.; Hamlet, A.F.; Lettenmaier, D.P. Implications of global climate change for snowmelt hydrology in the twenty-first century. Hydrol. Process. 2009, 23, 962-972. [CrossRef]

31. Barnett, T.P.; Pierce, D.W.; Hidalgo, H.G.; Bonfils, C.; Santer, B.D.; Das, T.; Bala, G.; Wood, A.W.; Nozawa, T.; Mirin, A.A. Human-induced changes in the hydrology of the western United States. Science 2008, 319, 1080-1083. [CrossRef] [PubMed]

32. Brabets, T.P.; Walvoord, M.A. Trends in streamflow in the Yukon River Basin from 1944 to 2005 and the influence of the pacific decadal oscillation. J. Hydrol. 2009, 371, 108-119. [CrossRef]

33. Jones, J.A. Hydrologic responses to climate change: Considering geographic context and alternative hypotheses. Hydrol. Process. 2011, 25, 1996-2000. [CrossRef]

34. Wilson, D.; Hisdal, H.; Lawrence, D. Has streamflow changed in the nordic countries?-Recent trends and comparisons to hydrological projections. J. Hydrol. 2010, 394, 334-346. [CrossRef]

35. Xu, C.; Chen, Y.; Hamid, Y.; Tashpolat, T.; Chen, Y.; Ge, H.; Li, W. Long-term change of seasonal snow cover and its effects on river runoff in the Tarim River Basin, northwestern China. Hydrol. Process. 2009, 23, 2045-2055. [CrossRef]

36. Guo, H.; Hu, Q.; Jiang, T. Annual and seasonal streamflow responses to climate and land-cover changes in the Poyang Lake Basin, China. J. Hydrol. 2008, 355, 106-122. [CrossRef]

37. Sagarika, S.; Kalra, A.; Ahmad, S. Evaluating the effect of persistence on long-term trends and analyzing step changes in streamflows of the continental United States. J. Hydrol. 2014, 517, 36-53. [CrossRef]

38. Tohver, I.M.; Hamlet, A.F.; Lee, S.Y. Impacts of 21st-century climate change on hydrologic extremes in the pacific northwest region of north America. J. Am. Water Resour. Assoc. 2014, 50, 1461-1476. [CrossRef]

39. Lins, H.F.; Slack, J.R. Streamflow trends in the United States. Geophys. Res. Lett. 1999, 26, 227-230. [CrossRef]

40. Norton, P.A.; Anderson, M.T.; Stamm, J.F. Trends in Annual, Seasonal, and Monthly Streamflow Characteristics at 227 Streamgages in the Missouri River Watershed, Water Years 1960-2011; US Geological Survey: Reston, VA, USA, 2014. 
41. United States Department of Agriculture. Summary Report: 1997 National Resources Inventory (Revised December 2000). Available online: http://www.nrcs.usda.gov/Internet/FSE_DOCUMENTS/ nrcs143_012094.pdf (accessed on 23 December 2015).

42. South Dakota Department of Agriculture, Ecosystem Research Group. Draft Coordinated Plan for Natural Resources Conservation; South Dakota Department of Agriculture: Pierre, South Dakota, USA, 2006.

43. South Dakota Department of Agriculture and HDR Engineering Inc. South Dakota Coordinated Plan for Natural Resources Conservation; State Conservation Commission: Pierre, SD, USA, 2012.

44. National Agricultural Statistics Service. Quickstats. Available online: http://quickstats.nass.usda.gov/ (accessed on 1 July 2015).

45. South Dakota Office of Climatology. South Dakota Climate and Weather. Available online: http:/ / climate.sdstate.edu/climate_site/climate.htm (accessed on 1 July 2015).

46. Saad, D.A.; Schwarz, G.E.; Robertson, D.M.; Booth, N.L. A multi-agency nutrient dataset used to estimate loads, improve monitoring design, and calibrate regional nutrient sparrow models1. J. Am. Water Resour. Assoc. 2011, 47, 933-949. [CrossRef] [PubMed]

47. Ahiablame, L.; Engel, B.; Chaubey, I. An optimization method for estimating constituent mean concentrations in base flow-dominated flow. J. Am. Water Resour. Assoc. 2013, 49, 1167-1178. [CrossRef]

48. The Nature Conservancy. Indicators of Hydrologic Alteration Version 7.1: User's Manual; The Nature Conservancy: Arlington, VA, USA, 2009.

49. Hamed, K.H.; Rao, A.R. A modified Mann-Kendall trend test for autocorrelated data. J. Hydrol. 1998, 204, 182-196. [CrossRef]

50. Durbin, J.; Watson, G.S. Testing for serial correlation in least squares regression. I. Biometrika 1950, 37, 409-428. [PubMed]

51. Savin, N.E.; White, K.J. The Durbin-Watson test for serial correlation with extreme sample sizes or many regressors. Econom. J. Econom. Soc. 1977, 45, 1989-1996. [CrossRef]

52. Hirsch, R.M.; Slack, J.R. A Non-parametric trend test for seasonal data with serial dependence. Water Resour. Res. 1984, 20, 727-732. [CrossRef]

53. Yue, S.; Pilon, P.; Phinney, B.; Cavadias, G. The influence of autocorrelation on the ability to detect trend in hydrological series. Hydrol. Process. 2002, 16, 1807-1829. [CrossRef]

54. Mann, H.B. Nonparametric tests against trend. Econom. J. Econom. Soc. 1945, 13, 245-259. [CrossRef]

55. Zhang, X.; Zhang, L.; Zhao, J.; Rustomji, P.; Hairsine, P. Responses of streamflow to changes in climate and land use/cover in the Loess Plateau, China. Water Resour. Res. 2008. [CrossRef]

56. Sen, P.K. Estimates of the regression coefficient based on Kendall's tau. J. Am. Stat. Assoc. 1968, 63, 1379-1389. [CrossRef]

57. Hirsch, R.M.; Slack, J.R.; Smith, R.A. Techniques of trend analysis for monthly water quality data. Water Resour. Res. 1982, 18, 107-121. [CrossRef]

58. Salmi, T.A.M.; Anttila, P.; Ruoho-Airola, T.; Amnell, T. Detecting trends of annual values of atmospheric pollutants by the Mann-Kendall test and Den's slope estimates-the Excel template application makesens. Air Qual. Res. 2002, 7-35.

59. Chiew, F.H. Estimation of rainfall elasticity of streamflow in Australia. Hydrol. Sci. J. 2006, 51, 613-625. [CrossRef]

60. Schaake, J.C.; Waggoner, P.E. From climate to flow. In Climate Change and US Water Resources; John Wiley \& Sons, Inc: New York, NY, USA, 1990; pp. 177-206.

61. Fu, G.; Chiew, F.; Charles, S.; Mpelasoka, F. Assessing precipitation elasticity of streamflow based on the strength of the precipitation-streamflow relationship. In Proceedings of the 19th International Congress on Modelling and Simulation, Perth, Australia, 12-16 December 2011; pp. 3567-3572.

62. Sankarasubramanian, A.; Vogel, R.M.; Limbrunner, J.F. Climate elasticity of streamflow in the United States. Water Resour. Res. 2001, 37, 1771-1781. [CrossRef]

63. Yao, C.; Zhu, H.; Lu, X.; Liu, Y. Study on the impact of socio-economic driving factors of land use change on the ecosystem service values in Fujian province. J. Nat. Resour. 2009, 24, 225-233.

64. Zheng, J.; Yu, X.; Deng, W.; Wang, H.; Wang, Y. Sensitivity of land-use change to streamflow in Chaobai River Basin. J. Hydrol. Eng. 2012, 18, 457-464. [CrossRef]

65. Garbrecht, J.; Van Liew, M.; Brown, G.-O. Trends in precipitation, streamflow, and evapotranspiration in the Great Plains of the United States. J. Hydrol. Eng. 2004, 9, 360-367. [CrossRef] 
66. Knapp, H.V. Analysis of streamflow trends in the upper midwest using long-term flow records. In Proceedings of World Water and Environmental Resources Congress, Anchorage, AK, USA, 15-19 May 2005; pp. 15-19.

67. Kustu, M.D.; Fan, Y.; Rodell, M. Possible link between irrigation in the US High Plains and increased summer streamflow in the Midwest. Water Resour. Res. 2011. [CrossRef]

68. United States Environmental Protection Agency. Climate Change and South Dakota; United States Environmental Protection Agency: Washington, DC, USA, 1998.

69. Miller, L.D.; Driscoll, D.G. Streamflow Characteristics for the Black Hills of South Dakota, through Water Year 1993; US Department of the Interior, US Geological Survey: Rapid city, SD, USA, 1998.

70. Fontaine, T.; Klassen, J.; Cruickshank, T.; Hotchkiss, R. Hydrological response to climate change in the Black Hills of South Dakota, USA. Hydrol. Sci. J. 2001, 46, 27-40. [CrossRef]

71. Douglas, E.; Vogel, R.; Kroll, C. Trends in floods and low flows in the United States: Impact of spatial correlation. J. Hydrol. 2000, 240, 90-105. [CrossRef]

72. Sikka, A.; Samra, J.; Sharda, V.; Samraj, P.; Lakshmanan, V. Low flow and high flow responses to converting natural grassland into bluegum (eucalyptus globulus) in nilgiris watersheds of south India. J. Hydrol. 2003, 270, 12-26. [CrossRef]

73. Karl, T.R.; Knight, R.W. Secular trends of precipitation amount, frequency, and intensity in the United States. Bull. Am. Meteorol. Soc. 1998, 79, 231-241. [CrossRef]

74. Iowa Flood Center and Iowa Institute of Hydraulic Research (IIHR); The University of Iowa; C. Maxwell Stanley Hydraulics Laboratory. Hydrologic Assessment of the Middle Raccoon River Watershed. Available online: http:/ /iowafloodcenter.org/wordpress/wp-content/uploads/2011/09/Middle-RaccoonHydrologic-Assessment-Oct-2014.pdf (accessed on 23 December 2015).

75. McCabe, G.J.; Wolock, D.M. A step incraese in streamflow in the conterminous United States. Geophys. Res. Lett. 2002. [CrossRef]

76. Hodgkins, G.A.; Dudley, R.W. Changes in the timing of winter-spring streamflows in eastern North America, 1913-2002. Geophys. Res. Lett. 2006. [CrossRef]

77. Small, D.; Islam, S.; Vogel, R.M. Trends in precipitation and streamflow in the eastern US: Paradox or perception? Geophys. Res. Lett. 2006. [CrossRef]

78. Karl, T.R.; Melillo, J.M.; Peterson, T.C. Global Climate Change Impacts in the United States; United States Global Change Research Program: Washington, DC, USA, 2009.

79. Tang, C.; Crosby, B.T.; Wheaton, J.M.; Piechota, T.C. Assessing streamflow sensitivity to temperature increases in the Salmon River Basin, Idaho. Global Planet. Change 2012, 88, 32-44. [CrossRef]

80. German Advisory Council on Global Change (WBGU). World in Transition: Ways Towards Sustainable Management of Freshwater Resources; German Advisory Council on Global Change (WBGU): Bremerhaven, Germany, 1997; pp. 1-419.

81. Hönigová, I.; Vačkář, D.; Lorencová, E.; Melichar, J.; Götzl, M.; Sonderegger, G.; Oušková, V.; Hošek, M.; Chobot, K. Survey on Grassland Ecosystem Services; EEA-European Topic Centre on Biological Diversity: Prague, Czech Republic, 2012; pp. 1-78.

82. Driscoll, D.G.; Bunkers, M.J.; Carter, J.M.; Stamm, J.F.; Williamson, J.E. Thunderstorms and Flooding of August 17, 2007, with a Context Provided by a History of Other Large Storm and Flood Events in Black Hills Area of South Dakota; U.S. Department of Interior, United States Geological Survey: Reston, VA, USA, 2010.

(C) 2016 by the authors; licensee MDPI, Basel, Switzerland. This article is an open access article distributed under the terms and conditions of the Creative Commons by Attribution (CC-BY) license (http://creativecommons.org/licenses/by/4.0/). 